\title{
Origin and transformation of ambient volatile organic compounds during a dust-to-haze episode in northwest China
}

\author{
Yonggang Xue $\mathrm{e}^{1,2,3,4}$, Yu Huang ${ }^{1,2,3,4}$, Steven Sai Hang Ho ${ }^{1,2,5}$, Long Chen ${ }^{1,2,3,4}$, Liqin Wang ${ }^{1,2,3,4}$, Shuncheng Lee ${ }^{6}$, \\ and Junji Cao ${ }^{1,2,3,4}$ \\ ${ }^{1}$ Key Lab of Aerosol Chemistry \& Physics, Institute of Earth Environment, Chinese Academy of Sciences, \\ Xi'an 710061, China \\ ${ }^{2}$ State Key Lab of Loess and Quaternary Geology (SKLLQG), Institute of Earth Environment, \\ Chinese Academy of Sciences, Xi'an 710061, China \\ ${ }^{3}$ Shaanxi Key Laboratory of Atmospheric and Haze-fog Pollution Prevention, Institute of Earth Environment, \\ Chinese Academy of Sciences, Xi' an 710061, China \\ ${ }^{4}$ CAS Center for Excellence in Quaternary Science and Global Change, Xi' an 710061, China \\ ${ }^{5}$ Division of Atmospheric Sciences, Desert Research Institute, Reno, Nevada, USA \\ ${ }^{6}$ Department of Civil and Environmental Engineering, The Hong Kong Polytechnic University, \\ Hung Hom, Hong Kong SAR, China
}

Correspondence: Yu Huang (huangyu@ieecas.cn) and Junji Cao (cao@loess.llqg.ac.cn)

Received: 25 October 2019 - Discussion started: 10 December 2019

Revised: 26 March 2020 - Accepted: 3 April 2020 - Published: 8 May 2020

\begin{abstract}
The high contribution of secondary organic aerosol to the loading of fine particle pollution in China highlights the roles of volatile organic compound (VOC) oxidation. In this respect, particulate active metallic oxides in dust, like $\mathrm{TiO}_{2}$ and $\mathrm{Fe}$ ions, were proposed to influence the photochemical reactions of ambient VOCs. A case study was conducted at an urban site in Xi' an, northwest China, to investigate the origin and transformation of VOCs during a windblown dust-to-haze pollution episode, and the assumption that dust would enhance the oxidation of VOCs was verified. Local vehicle exhaust $(25 \%)$ and biomass burning $(18 \%)$ were found to be the two largest contributors to ambient VOCs. In the dust pollution period, a sharp decrease in the loading of VOCs and the aging of their components were observed. Simultaneously, the secondary oxygenated VOC fraction (i.e., methylglyoxal) increased. Source strength, physical dispersion, and regional transport were eliminated as major factors for the variation of ambient VOCs. In another aspect, about a 2- to 3-fold increase in the loading of iron $(\mathrm{Fe})$ and titanium (Ti) was found in the airborne particles, together with a fast decrease in trans-/cis2-butene ratios, which demonstrated that dust can acceler-
\end{abstract}

ate the oxidation of ambient VOCs and the formation of secondary organic aerosol (SOA) precursors.

\section{Introduction}

Secondary aerosols are important components of fine particles in China, which could contribute to about $30 \%$ to $77 \%$ of $\mathrm{PM}_{2.5}$ loading; in this respect, secondary organic aerosols (SOAs) take about half of the loading (Huang et al., 2014). Guo et al. (2014) believed that gaseous emissions of volatile organic compounds (VOCs) and nitrogen oxides $\left(\mathrm{NO}_{x}\right)$ were responsible for the large secondary PM formation. OH-initiated oxidation of $m$-xylene was found to cause the coating thickness of black carbon, which further induced the increase in particle size (1.5 to 10.4 times) and effective density (from 0.43 to $1.45 \mathrm{~g} \mathrm{~cm}^{-3}$ ) (Guo et al., 2016).

Solid-gas heterogeneous reactions would cause the transformation of gaseous pollutants and change the property of particles (Zhang et al., 2000, 2003; He et al., 2014). Recently, the oxidation of organic and inorganic gas on particle surfaces through the transition-metal-catalyzed chain reaction was frequently found to play an important role on the trans- 
formation of ambient gas pollutants (Chu et al., 2019). Mineral dust is one of the most important sources of transition metals, like iron $(\mathrm{Fe})$ and titanium $(\mathrm{Ti})$, in the natural environment (Chen et al., 2012). In addition, mineral dust is one kind of the most abundant components of global airborne PM, and about 1600 to $2000 \mathrm{Tg}$ of mineral dust is transformed into aerosols annually from major deserts (Ginoux et al., 2001). Furthermore, the surface of mineral dust provides plenty of reactive sites for multiple atmospheric trace gas reactions (Cwiertny et al., 2008). As a result, dust is considered to serve as a catalyst for reactive gases and to modify the photochemical processes (Dentener et al., 1996; Dickerson et al., 1997).

With the controlled experiment of sulfate formation on mineral dust, Zhang et al. (2019) found that under appropriate humidity and particle acidity, a surface transition-metalcatalyzed chain reaction together with nitrate would greatly accelerate the sulfate's formation on the surface of mineral dust (Zhang et al., 2019). In another aspect, solid-gas heterogeneous photochemical reactions of organic compounds were also reported on the illuminated surface of semiconductor metal oxides in the natural environment, in particular $\mathrm{TiO}_{2}$ (Chen et al., 2012). Co-existent heterogeneous photochemical reactions of $\mathrm{SO}_{2}, \mathrm{NO}_{2}$, and VOCs on the surface of mineral dust were investigated in recent years. Both synergistic and suppressing effects of VOCs on the formation of sulfate were found, which indicated the competition of reactive oxygen species and active sites between VOCs and inorganic gas pollutants (Chu et al., 2019; Song et al., 2019). In addition, oxidized products, like formate and acetate species, were observed in the coexistence reaction, which highlights the possibility of further oxidation of VOCs on the mineral dust (He et al., 2014). In northwest China, dust from both local sources and long-range transport is one of the most important components of particulate matter of $<2.5 \mu \mathrm{m}$ in diameter $\left(\mathrm{PM}_{2.5}\right)$ (Huang et al., 2014). Xi'an has a population of $\sim 8$ million (Feng et al., 2016). The sharp increase in vehicles and other human activities has led to high emissions of VOCs and $\mathrm{NO}_{x}$ (Li et al., 2017). Observations showing simultaneous high dust loading and elevated concentrations of VOCs and $\mathrm{NO}_{x}$ suggest possible impacts from heterogeneous reactions on dust particles (Huang et al., 2014; Li et al., 2017). The present study was conducted to investigate the origin and transformation of ambient VOCs during a severe dust-to-haze episode in winter. The transformation and the related chemical processing of ambient VOCs and the related changes in the composition of $\mathrm{PM}_{2.5}$ were studied within a typical windblown dust-to-haze episode. The potential pathway of VOC oxidation in the windblown dust-to-haze formation process was explored.

\section{Materials and methods}

\subsection{Sampling site}

An observation site $\left(109^{\circ} 00^{\prime} 7^{\prime \prime} \mathrm{E}, 34^{\circ} 13^{\prime} 22^{\prime \prime} \mathrm{N}\right)$ managed by Xi'an Jiaotong University was used in this study (Fig. 1). All sampling equipment was deployed on the rooftop of a $15 \mathrm{~m}$ tall academic building. No obvious stationary pollution sources were found nearby, and the location can be considered as a typical urban location in Xi'an (Q. Zhang et al., 2015).

\subsection{Field sampling}

A severe dust-to-haze episode was observed in Xi' an and the surrounding areas from 8 to 13 November 2016, and samples were continuously collected during this period to investigate the chemical compositions of both VOCs and fine PM. A total of 57 non-methane VOC species (i.e., $\mathrm{C}_{2}-\mathrm{C}_{12}$ saturated and unsaturated aliphatic and aromatic VOCs) were sampled hourly into offline multi-bed adsorbent tubes; the measured 57 VOCs were defined as VOCPAMs. The loaded tubes were analyzed using a thermal desorption and gas chromatography/mass spectrometry (TD-GC/MS) method. In previous developmental work, humidity and temperature during sampling were found to significantly impact the analyses; for this study, all sample collections were made under optimized conditions (Ho et al., 2017, 2018). Sixteen airborne carbonyls (including mono- and dicarbonyls) were collected over diurnal cycles (i.e., 20:00-08:00 and 08:00-20:00 local time, LT) by 2,4-dinitrophenylhydrazine (DNPH) coated cartridges. Detailed sampling and analytical procedures for VOCs and carbonyls can be found in previous publications (Ho et al., 2017; Dai et al., 2012).

$\mathrm{PM}_{2.5}$ filter samples were sampled with mini-volume samplers (model MiniVol, Airmetrics Co., Oregon, USA) by an overline flow rate of $5 \mathrm{~L} \mathrm{~min}^{-1}$ (Cao et al., 2005). Fine PM was sampled with $47 \mathrm{~mm}$ quartz microfiber filters (Whatman QM-A, Maidstone, UK), and the filters were pre-heated at $900^{\circ} \mathrm{C}$ for $3 \mathrm{~h}$ before sampling. The loaded filters were transferred into clean polystyrene petri dishes and stored in a freezer.

\subsection{Chemical analyses}

Analytical procedures for VOC analysis have been described previously (Ho et al., 2017). In brief, the analytes in the adsorbent tubes were firstly desorbed in a thermal desorption unit (Series 2 UNITY-xr system with ULTRA-xr, Markes International Ltd., UK) coupled to a GC/MS (7890A/5977B, Agilent Technologies, Santa Clara, CA, USA). The loaded tubes were transferred into the TD unit and blown with ultrahigh purity $\mathrm{He}$ gas. The targeted VOCs were desorbed at $330^{\circ} \mathrm{C}$ within $8 \mathrm{~min}$ and then refocused onto a cryogenic trap (U-T1703P-2S, Markes) at $-15^{\circ} \mathrm{C}$. The targeted VOCs were transferred to a cold GC capillary column head (Rtx ${ }^{\circledR}$ - 

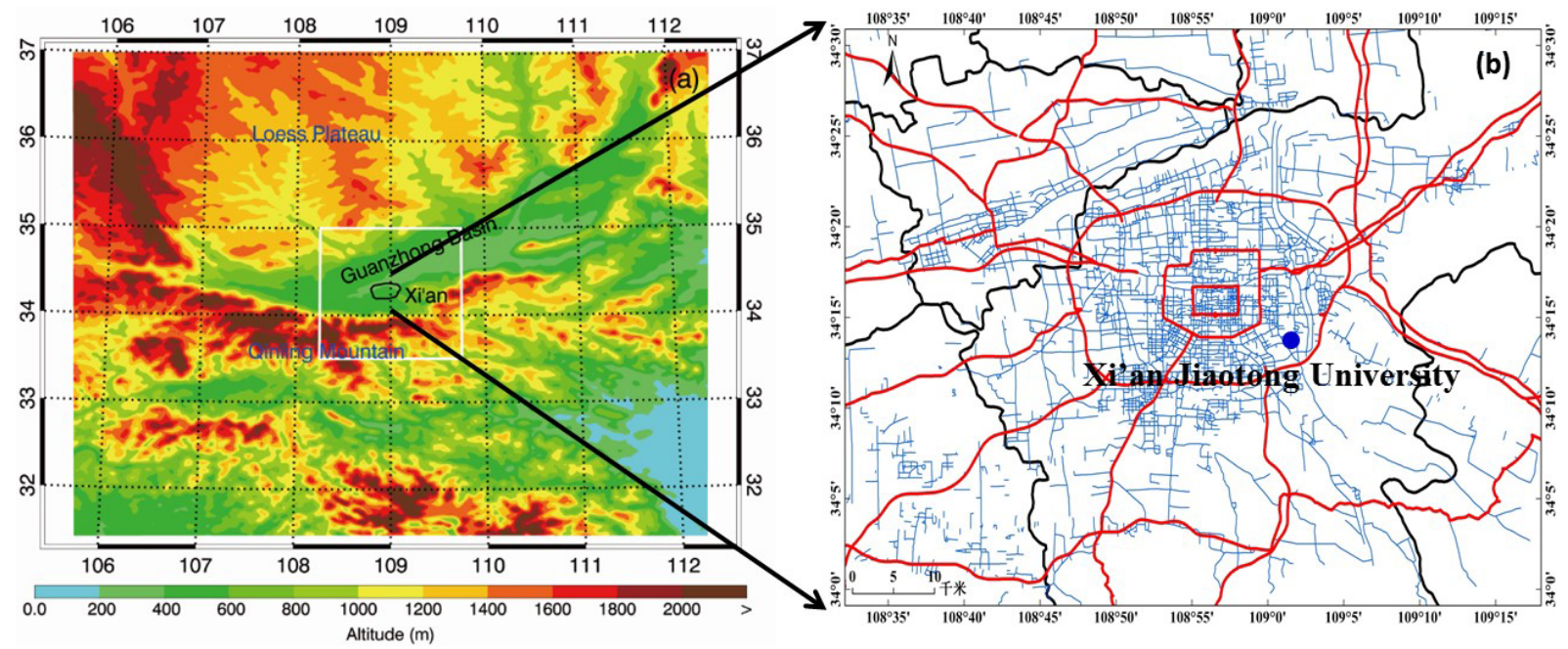

Figure 1. Regional and local maps of the study area: (a) regional map showing the location of Xi' an and the surrounding geography; (b) local map of Xi' an showing the sampling site (blue dot), main roads (red lines), and secondary roads (blue lines).

$1,105 \mathrm{~m} \times 0.25 \mathrm{~mm} \times 1 \mathrm{~mm}$ film thickness, Restek Corporation, USA) at $-45^{\circ} \mathrm{C}$. The chromatographic condition can be found in our previous work (Ho et al., 2017).

For carbonyl compounds, the DNPH cartridges were firstly eluted with acetonitrile (HPLC/GCMS grade, J \& K Scientific Ltd., Ontario, Canada) (Dai et al., 2012). The extracts were analyzed with a typical high-pressure liquid chromatography (HPLC) system (Series 1200; Agilent Technologies) equipped with photodiode array detector. The column was matched with a $4.6 \times 250 \mathrm{~mm}$ Spheri-5 ODS $5 \mu \mathrm{m} \mathrm{C}-18$ reversed-phase column (Perkin-Elmer Corp., Norwalk, CT) (Dai et al., 2012; Ho et al., 2011).

The particulate organic carbon (OC) and elementary carbon (EC) were analyzed with a DRI model 2001 carbon analyzer (Atmoslytic, Inc., Calabasas, CA, USA) (Chow et al., 2007, 1993). Anions $\left(\mathrm{Cl}^{-}, \mathrm{NO}_{3}^{-}\right.$, and $\left.\mathrm{SO}_{4}^{2-}\right)$ and cations $\left(\mathrm{Na}^{+}, \mathrm{NH}_{4}^{+}, \mathrm{K}^{+}, \mathrm{Mg}^{2+}\right.$, and $\left.\mathrm{Ca}^{2+}\right)$ in particles were determined in aqueous extracts of the sample filters. Detailed extraction and analytical procedures were presented in a previous publication (Zhang et al., 2011). The abundances of 25 particulate elements $(\mathrm{Na}, \mathrm{Mg}, \mathrm{Al}, \mathrm{Si}, \mathrm{S}, \mathrm{Cl}, \mathrm{K}, \mathrm{Ca}, \mathrm{Sc}$, $\mathrm{Ti}, \mathrm{V}, \mathrm{Cr}, \mathrm{Mn}, \mathrm{Fe}, \mathrm{Co}, \mathrm{Ni}, \mathrm{Cu}, \mathrm{As}, \mathrm{Se}, \mathrm{Br}, \mathrm{Sr}, \mathrm{Ba}, \mathrm{Pb}, \mathrm{Ga}$, $\mathrm{Zn}$ ) were measured by energy dispersive $\mathrm{X}$-ray fluorescence (ED-XRF) spectrometry (Epsilon 4 ED-XRF, PANalytical B.V., the Netherlands). The $\mathrm{X}$-ray source was matched with a metal-ceramic X-ray tube with an $\mathrm{Rh}$ and $\mathrm{Ag}$ anode, and the $\mathrm{X}$-ray source was operated at a maximum current of $3 \mathrm{~mA}$ and a maximum accelerating voltage of $50 \mathrm{kV}$ (maximum power $15 \mathrm{~W}$ ).

\subsection{Quality control}

The minimum detection limits (MDLs) of the VOCs were in the range of $0.003-0.042 \mathrm{ppbv}$ with a $3 \mathrm{~L}$ sampling volume
(Table S1 in the Supplement). The measurement precision at 2 ppbv was $\leq 5 \%$ (Ho et al., 2017, 2018). Three field blank samples were collected within each sampling day, and they were analyzed using the same procedures as those for the ambient air samples. Most target compounds were not detected in the field blanks, and propylene, benzene, and toluene were below their MDLs $(<0.23 \mathrm{~g}$ per tube and $<10 \%$ of the arithmetic mean of ambient samples). No breakthrough $(\sim 0 \%)$ was observed for $\mathrm{VOC}_{\text {PAMS }}$ except for $\mathrm{C}_{2}-\mathrm{C}_{3}$ hydrocarbons, which were $<10 \%$ when the air temperature was $>30^{\circ} \mathrm{C}$. The MDLs for the carbonyl target compounds were between 0.009 and $0.067 \mathrm{ppbv}$ at a sampling volume of $3.6 \mathrm{~m}^{3}$. Negligible breakthrough $(<5 \%)$ was found under the sampling conditions and flow rates in the field.

\section{Results and discussion}

\subsection{Origins of ambient VOCs during dust and fine particle pollution events}

In the present study, the mixing ratio of the sum of nonmethane hydrocarbon was $36.0 \pm 15.7 \mathrm{ppbv}$, which was lower compared to those in Beijing and Guangzhou with values of 51.0 and $47.8 \mathrm{ppbv}$, respectively (Ho et al., 2004; Liu et al., 2008b). Similar levels of alkenes were seen in the cities of Beijing (9.4 ppbv) and Guangzhou ( $8.2 \mathrm{ppbv})$ compared to that in the present study (9.2 ppbv, Table S2) (Ho et al., 2004; Liu et al., 2008b). Unexpectedly, the levels of aromatics were slightly higher in Xi' an (10.3 ppbv) than in Beijing ( $9.6 \mathrm{ppbv}$ ) and $50 \%$ higher than in Guangzhou (6.8 ppbv, Shao et al., 2009; Zou et al., 2015). In this respect, ethylene, ethane, toluene, isopentane, propane, $n$-butane, isobutane, propylene, $n$-pentane, and benzene were the 10 most abun-

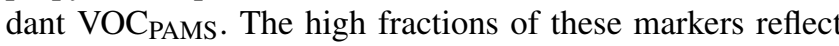


strong emissions from traffic and coal combustion or from biomass burning (Liu et al., 2008a; Ho et al., 2009; Huang et al., 2015; Fan et al., 2014; Z. Zhang et al., 2015). Previous studies found higher contributions of non-fossil sources to carbonaceous aerosols in Xi'an than in Beijing ( $\mathrm{Ni}$ et al., 2018). Generally, non-fossil emissions mainly originate from biomass burning (Ni et al., 2018), and the higher contribution of non-fossil sources to carbonaceous aerosols in Xi' an would indicate that remarkable biomass burning activities exist in $\mathrm{Xi}^{\prime}$ an and the surrounding areas (Huang et al., 2014; Xu et al., 2016).

Receptor models and correlations between individual VOCs have been used for source assessments. In this study, a significant correlation $\left(R^{2}=0.62, p<0.05\right.$, slope of 1.59) was found for a least squares regression between toluene and benzene (Fig. S1 in the Supplement). The ratio of toluene to benzene (T/B) has been shown to be different among combustion sources; for example, Liu et al. (2006) reported T/B ratios of 1.5-2.0 in gasoline-related emissions collected in a tunnel. In contrast, T/B ratios ranged from $0.23-0.68$ and 0.13-0.71 for biomass burning and coal combustion, respectively (Z. Zhang et al., 2015). The T/B ratios in our samples $\left(R^{2}=0.62, p<0.05\right.$, slope of 1.59) implied a strong impact from traffic on the ambient VOCs in Xi'an. Significant correlations $(p<0.05)$ were observed among $\mathrm{C}_{3}-\mathrm{C}_{5}$ alkanes: between propane and $n$-butane $\left(R^{2}=0.75\right.$, slope $\left.=0.91\right)$, $n$-pentane and isopentane $\left(R^{2}=0.85\right.$, slope $\left.=0.35\right)$, and trans-2-butene and cis-2-butene $\left(R^{2}=0.99\right.$, slope $\left.=0.84\right)$ (Fig. S1). The observed ratio of propane to $n$-butane in Xi' an was $1 / 1$, which is close to that (1.36) observed in the tunnel study cited above (Liu et al., 2008a). High loadings of $n$-pentane and isopentane are indicative of unburned vehicular emissions, and Liu et al. (2008b) reported a ratio of isopentane / $n$-pentane of 3 in tunnel air, which is consistent with the slope of 2.85 found in the present study. The ratios of T/B, trans-/cis-2-butene, propane/ $n$-butane, and $n$ pentane/isopentane indicated that gasoline emissions were a dominant source of ambient VOCs. The source apportionment by PMF (positive matrix factorization) model and the detailed description of source apportionment will be carried out in the following section.

A PMF model was used to identify the major pollution sources; the data input to the model was the mixing ratios and uncertainties in the mixing ratios of the VOCs for all valid samples collected during the study. Five sources were identified (Fig. S2), and the detailed process of source apportionment is given in the supplement. Biomass burning and gasoline exhaust were the two most significant pollution sources, contributing $25 \%$ and $18 \%$, respectively. The combustion of LPG and CNG (25\%), diesel exhaust (15\%), and coal combustion (17\%) were also found to be important sources of ambient VOCs (Fig. S2). Biomass is commonly used for heating and cooking in rural areas of the basin in winter due to its low cost compared to natural gas and electricity. Consistent with our results, previous studies have found a high contribution of biomass burning and gasoline exhaust to the organic aerosol in the Guanzhong basin (Cao et al., 2005).

Clear air conditions occurred at the beginning of the sampling period, but severe dust and fine particle pollution events were observed afterward. The high dust event was defined by the loading of particulate matter $\leq 10 \mu \mathrm{m}$ with an aerodynamic diameter $\left(\mathrm{PM}_{10}\right)$ between 300 and $500 \mu \mathrm{g} \mathrm{m}^{-3}$, and these conditions occurred from 12:00 LT on 9 November to 13:00 LT on 10 November. The abatement of dust before the fine particle pollution event is referred to as the transition period (i.e., $\mathrm{PM}_{10}<300 \mu \mathrm{g} \mathrm{m}^{-3}$ and $\mathrm{PM}_{2.5}<100 \mu \mathrm{g} \mathrm{m}^{-3}$ ). The loading of $\mathrm{PM}_{2.5}$ subsequently increased, and heavy fine particle pollution $\left(\mathrm{PM}_{2.5}>100 \mu \mathrm{g} \mathrm{m}^{-3}\right)$ occurred after 18:00 LT on 11 November.

Ratios of individual VOCs can be used to identify the origins of the compounds and to study atmospheric aging processes due to the special composition of VOCs in a typical source and the different lifetimes of VOCs species (Xue et al., 2017; Z. Zhang et al., 2015). In addition, influences from meteorological variation and atmospheric transport also need to be considered when the potential sources of the compounds in ambient air are characterized. To investigate the impacts of air mass transport on VOC concentrations, we calculated air mass back trajectories using the NOAA HYSPLIT model for the dust event (Fig. S4a) and for the fine particle pollution episode (Fig. S4b) (Stein et al., 2015; Rolph et al., 2017). The trajectories were calculated at an arrival height of $500 \mathrm{~m}$ above ground level at the observation site. In view of the short atmospheric lifetimes of VOCs (for example, isoprene $\sim 1.4 \mathrm{~h}$; propylene $\sim 5.3 \mathrm{~h}$; toluene $2.1 \mathrm{~d}$ ) (Atkinson and Arey, 2003), 24 h back trajectories were used for this assessment.

Clear different air mass back trajectories and VOC ratios were observed between dust pollution and haze pollution periods. From 9 to 10 November (in the dust pollution period), the air mass reaching Xi' an passed over areas to the west of the city (i.e., Gansu province and the Ningxia Hui Autonomous Region) through long-range transport; after 11 November (formation of haze), the transport of air mass was mainly limited to areas around southern Xi'an. Differences in the chemical compositions of ambient VOCs in the dusty versus in the hazy events can clearly be seen (Fig. 2) in the ratios of toluene to benzene (T/B) (toluene: $\mathrm{K}_{\mathrm{OH}} 5.96 \times 10^{-12} \mathrm{~cm}^{3}$ molecule ${ }^{-1} \mathrm{~s}^{-1}$; benzene: $\mathrm{K}_{\mathrm{OH}} 1.22 \times 10^{-12} \mathrm{~cm}^{3}$ molecule $\left.{ }^{-1} \mathrm{~s}^{-1}\right)$ and $m$-and $p$-xylene to ethylbenzene (X/E) ( $m$-xylene: $\mathrm{K}_{\mathrm{OH}} \quad 2.30 \times 10^{-11} \mathrm{~cm}^{3}$ molecule ${ }^{-1} \mathrm{~s}^{-1} ; \quad p$-xylene: $\mathrm{K}_{\mathrm{OH}}$ $1.43 \times 10^{-11} \mathrm{~cm}^{3}$ molecule ${ }^{-1} \mathrm{~s}^{-1}$; ethylbenzene: $\mathrm{K}_{\mathrm{OH}}$ $7.00 \times 10^{-12} \mathrm{~cm}^{3}$ molecule $\left.{ }^{-1} \mathrm{~s}^{-1}\right)$. During the clear and dust periods, the $\mathrm{T} / \mathrm{B}$ and $\mathrm{X} / \mathrm{E}$ ratios varied significantly with time of day; that is, the highest values for T/B (4.5-9.0) and $\mathrm{X} / \mathrm{E}(0.98-1.05)$ were seen during rush hour (07:00-09:00 and 17:00-19:00 LT), while the lowest values $(0.50-1.95$ for $\mathrm{T} / \mathrm{B}$ and $0.89-0.96$ for $\mathrm{X} / \mathrm{E}$ ) occurred in the early afternoon (i.e., 14:00-15:00 LT). The timings of the high $\mathrm{T} / \mathrm{B}$ and $\mathrm{X} / \mathrm{E}$ 
ratios suggest that fresh emissions from local traffic were the major source of the ambient VOCs, and this implies that long-range transport did not have a strong impact on the ambient VOCs during the clear or dust parts of the study (Ho et al., 2004; Liu et al., 2008a). During the transitional and fine PM pollution periods, both T/B and X/E varied but at relatively lower values compared to the earlier parts of the study (T/B: $3.33 \pm 1.97,2.21 \pm 0.86,1.91 \pm 0.74$, and $2.01 \pm 0.56$ in clear, dust, transitional, and fine particle pollution periods, respectively; X/E: $1.00 \pm 0.05,1.05 \pm 0.12$, $0.93 \pm 0.17$, and $0.95 \pm 0.13$ in clear, dust, transitional, and fine particle pollution periods, respectively). These synchronous lower values of $\mathrm{T} / \mathrm{B}$ and $\mathrm{X} / \mathrm{B}$ in transitional and fine particle pollution periods were indicative of aged air masses (Z. Zhang et al., 2015; Xue et al., 2017; Warneke et al., 2013).

Variations in the air mass transport pathway and $\mathrm{T} / \mathrm{B}$ or $\mathrm{X} / \mathrm{E}$ ratios during different sampling periods (clear, dust, transitional, fine particle pollution) confirmed that ambient VOCs were fresh in the clear and dust periods but relatively aged during the transitional and fine particle pollution periods (Z. Zhang et al., 2015; Xue et al., 2017; Warneke et al., 2013). This indicates that the long-range transport of air mass had a relatively weak influence on the ambient VOCs even during the high dust period. Otherwise, the composition of ambient VOCs should be relatively aged due to the long exposure time with dust transport. Indeed, emissions from local vehicular exhausts and biomass burning in Xi' an and the surrounding areas were the main contributors to ambient VOCs throughout our study.

\subsection{Transformation of VOCs between dust and fine particle events}

With the shading of dust, levels of ambient VOCs decreased with time, and the low concentrations (8.3-33.9 ppbv) were observed from 13:00 LT on 10 November to 01:00 LT on 11 November (Fig. 3). During the fine particle pollution period (12-13 November), the $\sum V_{\text {VOC }}$ PAMS increased, reaching an average of $38.0 \mathrm{ppbv}$ in the last $24 \mathrm{~h}$, compared to $19.0 \mathrm{ppbv}$ in the transitional period and $21.5 \mathrm{ppbv}$ in the first $12 \mathrm{~h}$ of the fine particle pollution episode (Fig. 3). This buildup of VOCs can be explained by weak dispersion and relatively shallow boundary layers $(400-1000 \mathrm{~m})$ during the event (Fig. 3). In addition, during this transition period, much lower ratios of $\mathrm{T} / \mathrm{B}$ and $\mathrm{X} / \mathrm{E}$ were observed in comparison with those in other periods (as mentioned in Sect. 3.1.2). We propose the possibility that windblown dust, which includes sustainable $\mathrm{TiO}_{2}$, can influence the atmospheric photochemistry of VOCs, which would accelerate the oxidation of ambient VOCs (Chu et al., 2019; Nie et al., 2014).

Changes in the emission sources and their strengths, physical dispersion, regional transport, and the aging of air masses could all affect VOC levels and composition (Xue et al., 2013, 2017). As a result, to evaluate the aging of ambient
VOCs in different periods, the impact of dust on the transformation of ambient VOCs, and the relative processes, the mentioned factors should be fully considered.

To evaluate the impact of source types on the variation of VOCs in the dust-to-haze episode, the diurnal variation of VOCs was depicted. During the clear and dust periods - and similar to the trends in T/B and X/E ratios - peaks in $\sum$ VOC $_{\text {PAMS }}$ were seen from 17:00 to 20:00 and 09:00 to 12:00 LT (Fig. 3), which highlighted the impacts of local traffic emissions (Liu et al., 2008a; Huang et al., 2015). 1,3-Butadiene is often used as a marker of gasoline-powered motor vehicles (Huang et al., 2015), while ethane is a key chemical marker for biomass and coal combustion (Liu et al., 2008a). Time series plots of 1,3-butadiene and ethane (Fig. S5) show that peaks in 1,3-butadiene mostly occurred during rush hour, while higher concentrations of ethane were seen during the night. These results support the conclusion that there were strong impacts from gasoline-powered motor vehicles in the daytime and from biomass burning or coal combustion for heating at night. In addition, winter heating activities was relatively active because of low temperatures during the transitional period, and this limited the possibility of reduced emission amounts. Hence, the variations of source strength were eliminated as being a major factor which caused the extremely low concentration and relative aged composition of ambient VOCs.

The variation of physical dispersion was also eliminated. With the shading of dust transport, shallow boundary layers were observed in the transitional period. For the clear and dust transport period, the boundary layer between 08:00 to $14: 00$ LT was relatively high $(1150-1500 \mathrm{~m})$. In contrast, the boundary layer height decreased sharply to $<800 \mathrm{~m}$ on 11 November in the transitional period. This limited the possibility that diffusion caused the sharp decrease in ambient VOCs in the transitional period.

The significant impact of air mass input was eliminated. Input of air mass would certainly cause the variations in the composition and loading of VOCs (Xue et al., 2014). In the present study, the long-range transport of air masses had limited impacts on the characteristic of ambient VOCs during the sampling period. In another aspect, relatively active VOCs would be firstly degraded; hence, the composition of ambient VOCs would be aged with long-range transport (Ho et al., 2009; Xue et al., 2017). In the present study, as mentioned above, the composition of ambient VOCs was relatively fresh under the long-range transport of air masses (during dust transport). In contrast, the composition of ambient VOC was relatively aged in the transitional period, and the air mass in this period was limited within Xi' an and the surrounding area. This phenomenon indicated that regional transport cannot be a major factor inducing the relatively aged composition and excess low loading of the ambient VOCs in the transitional period.

Synchronous changes in the VOC isomerides were found in the windblown dust-to-haze episode, which supplied the 


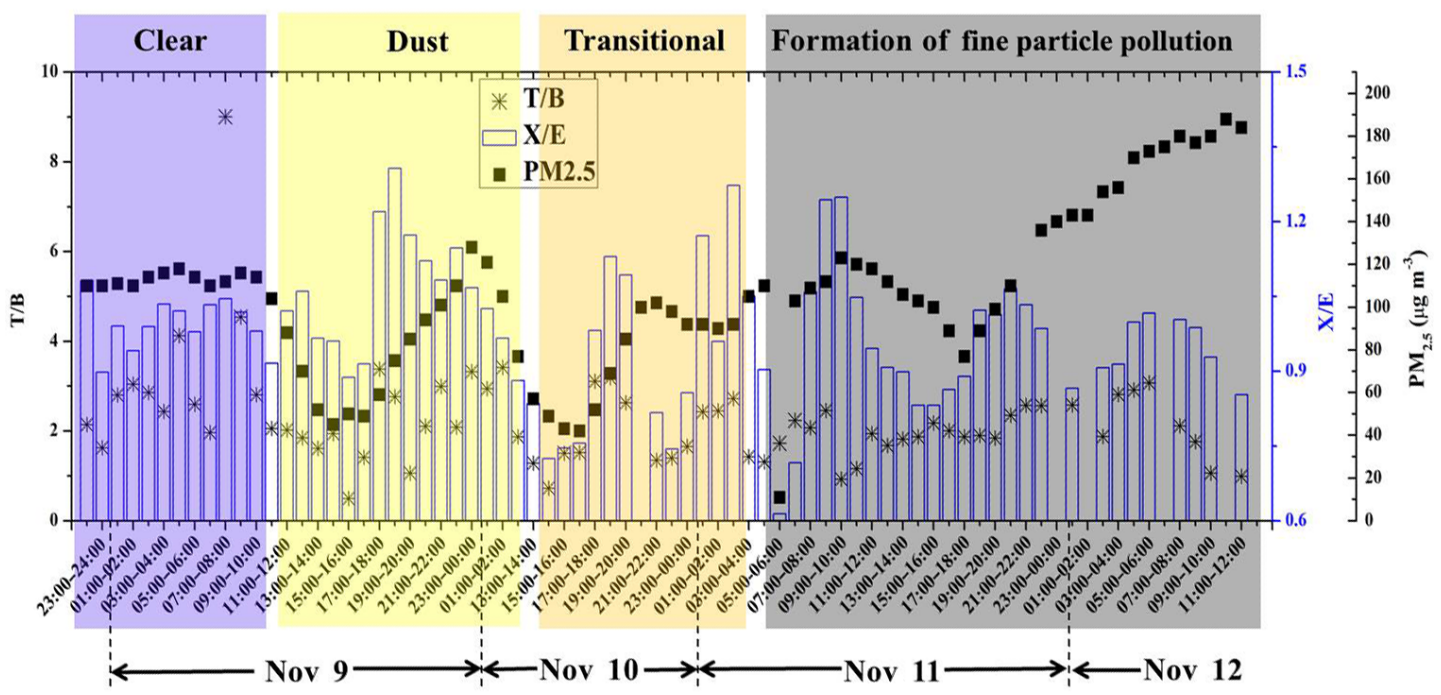

Figure 2. Variations in the ratios of indicator volatile organic compound low loading (VOC) species (toluene/benzene (T/B) and $m$-, $p$ xylene/ethylbenzene $(\mathrm{X} / \mathrm{E})$ ) and fine particle loadings during the study period.

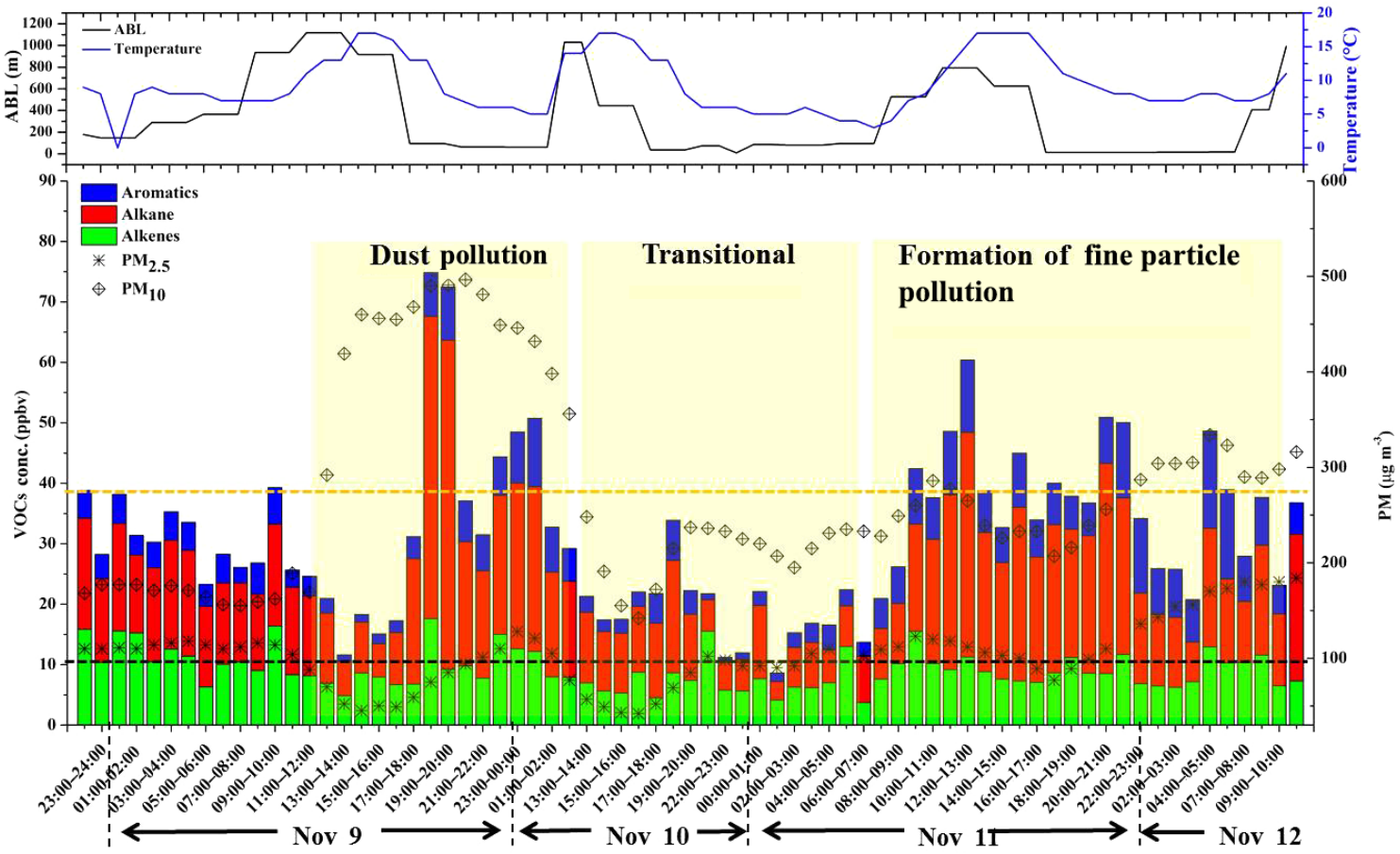

Figure 3. Temporal variations in volatile organic compound (VOC) concentrations and particle levels during the sampling period (913 November 2016).

evidence of the accelerated photochemistry reactions. In the present study, we found a fast decrease in trans-/cis-2-butene ratios during dust transporting, which confirmed the accelerated photochemical reactions of ambient VOCs (Fig. 4). Trans-2-butene and cis-2-butene are two isomerides that are mostly emitted from the same sources (Fang et al., 2017; Y. Zhang et al., 2015). Trans-2-butene has a higher pho- tochemical reaction rate with $\mathrm{OH}$ radicals in the atmosphere $\left(\mathrm{k}_{\mathrm{OH}} 6.40 \times 10^{-11} \mathrm{~cm}^{3}\right.$ molecule $\left.{ }^{-1} \mathrm{~s}^{-1}\right)$ than cis-2butene $\left(\mathrm{k}_{\mathrm{OH}} 5.64 \times 10^{-11} \mathrm{~cm}^{3}\right.$ molecule $\left.\mathrm{e}^{-1} \mathrm{~s}^{-1}\right)$ (Perring et al., 2013); hence, trans-/cis-2-butene ratios would decrease with the photochemical reactions (Y. Zhang et al., 2015). Firstly, relatively higher trans-/cis-2-butene ratios were observed during rush hour (evening rush hour 17:00-20:00 LT; 


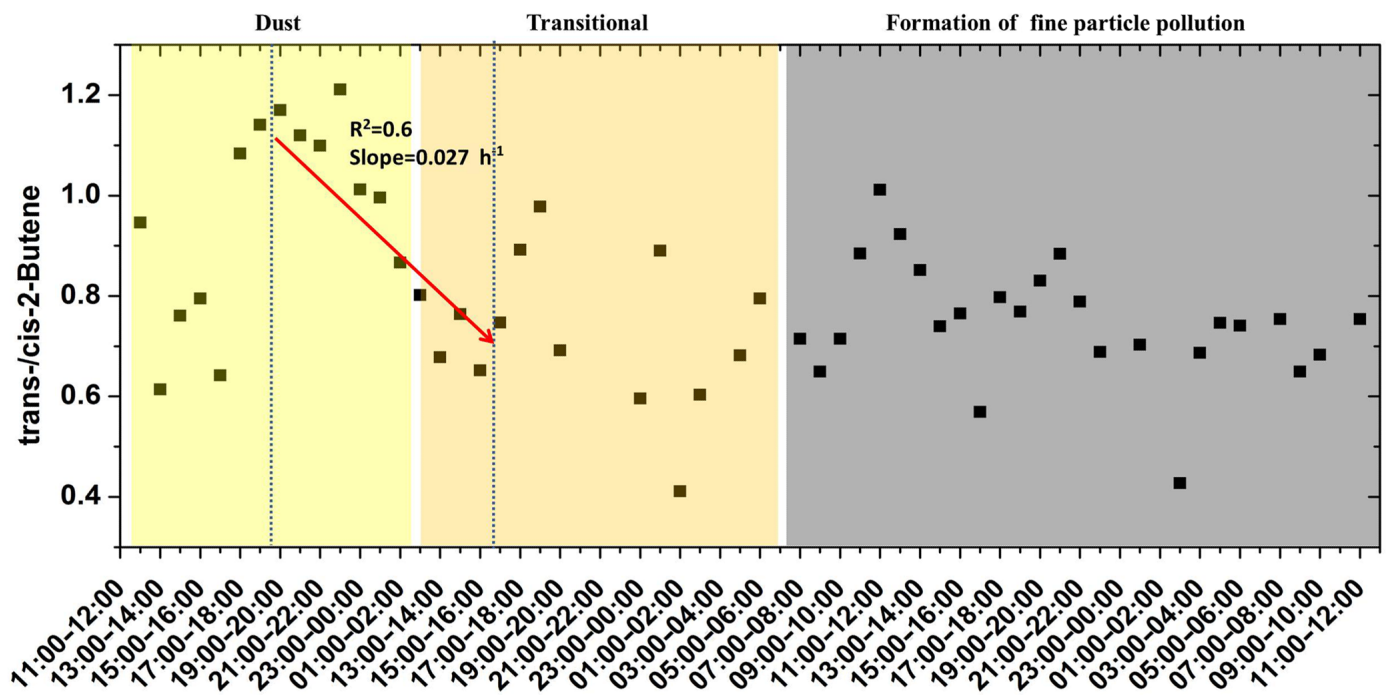

Figure 4. Temporal variations in trans-/cis-2-butene ratios in the dust, transitional, and fine particle pollution periods.

morning rush hour 07:00-10:00 LT) (Fig. 4), which indicated fresh emissions from local traffic activities (Y. Zhang et al., 2015). In addition, a sharp decrease in trans-/cis-2-butene ratios was observed from the later half of the windblown dust period to the end of the transitional period (Fig. 4). The quick shrinking of trans-2-butene compared to cis-2-butene in the dust pollution period indicated that the oxidation of ambient VOCs was accelerated in the period with high loading of the suspended dust particles (Y. Zhang et al., 2015).

A significant increase in particulate active metals was found in the dust pollution period, which further verified the promotion of dust on the heterogeneous reactions. Previous studies found that mineral dust can affect the chemistry of the atmosphere by scavenging gaseous compounds (Zhang et al., 2000; Chen et al., 2012); it can also promote heterogeneous reactions of atmospheric substances, including VOCs, because the particle surfaces can provide sites for photo-catalytic reactions (Cwiertny et al., 2008; Ndour et al., 2009). In the present study, iron (Fe) and titanium (Ti) contents of the particulate increased significantly during the period with dust transport (Fig. 5). In detail, the content of $\mathrm{Fe}$ increased from $19.3 \mu \mathrm{g} \mathrm{m}^{-3}$ on clear days to $40.8 \mu \mathrm{g} \mathrm{m}^{-3}$ on dust pollution days, and the content of Ti increased from 0.92 to $2.98 \mu \mathrm{g} \mathrm{m}^{-3}$. Hence, the huge increase in $\mathrm{Ti}$ and $\mathrm{Fe}$ concentrations in the particulate phase during the period of dust pollution could possibly promote the solid-gas photochemical reaction of the ambient VOCs, which would reasonably explain the relative low level and aged composition of ambient VOCs in this period (Chu et al., 2019; He et al., 2014; Song et al., 2019).

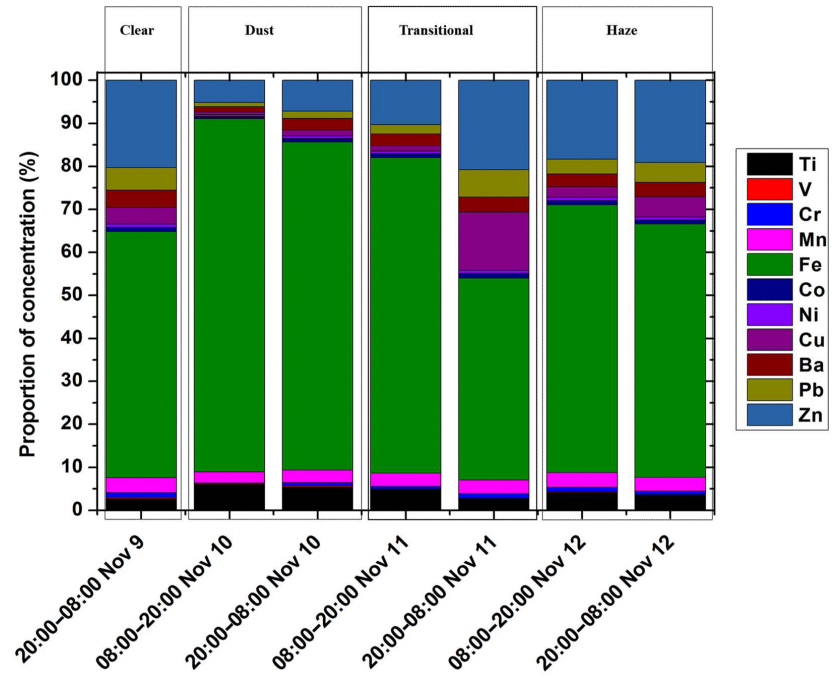

Figure 5. Composition of selected metallic elements in the $\mathrm{PM}_{2.5}$ samples.

\subsection{Variation of carbonyl compounds between dust and fine particle pollution periods: further formation of oxygenated VOCs with aging of primary VOCs}

The aging of primary VOCs and the formation of carbonyl compounds were observed synchronously as the fine particle pollution event developed (Figs. 3, 6a). As discussed above, relatively low $\mathrm{T} / \mathrm{B}$ and $\mathrm{X} / \mathrm{E}$ ratios were observed during the transitional and fine PM periods after the dust event (Sect. 3.2). In our study, the carbonyl levels increased after the clear and dust periods, and the highest levels were seen during the fine particle pollution event (Fig. 6a). Carbonyl compounds are produced from the primary sources and form through secondary processes (Dai et al., 2012; Duan et 

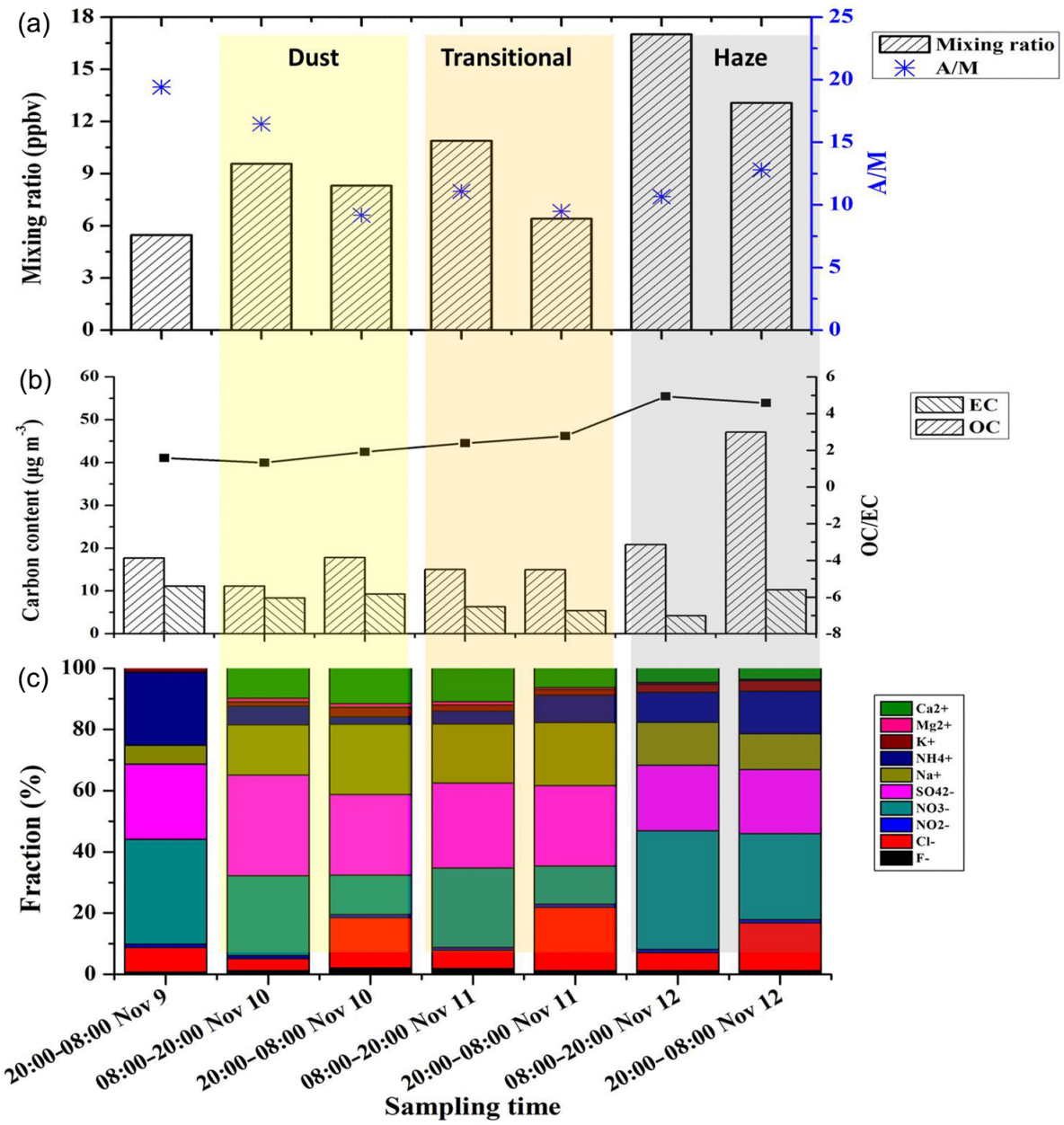

Figure 6. Variations in (a) the mixing ratios of 17 carbonyl compounds and acetone to methylglyoxal (A/M) ratios in the gas phase, (b) particulate carbon fractions, and (c) particulate water-soluble ions during the study period.

al., 2012). We found higher carbonyl concentrations during daytime than at night (Fig. 6a). This is consistent with previous studies in Xi'an (Dai et al., 2012), which confirmed the secondary formation of carbonyl compounds under sunlight illumination.

Methylglyoxal is generally considered to be a secondary species, while acetone is mainly from primary emissions; the ratio of acetone to methylglyoxal $(\mathrm{A} / \mathrm{M})$ has been used as an indicator of air mass aging (Dai et al., 2012; Liu et al., 2006). In the present study, A/M ranged from 12 to 14 during the clear period and the first half of the dust period but then dropped sharply and stayed between 6 and 9 during the later parts of the dust pollution period, the transitional period, and the high PM event (Fig. 6a). Increases in the abundance of carbonyl compounds and lower $\mathrm{A} / \mathrm{M}$ ratios suggested relatively stronger aging of the air masses, which is further evidence of the fast degradation of VOCs in the late half of the windblown dust event, and the primary VOCs were oxidized and served as precursors of SOA. In consequence, composi- tion of particles changed with the oxidation of ambient VOCs across the sampling periods.

\subsection{Variations of $\mathbf{P M}_{2.5}$ chemical composition during dust and fine $P M$ pollution periods}

Significant variations of water-soluble inorganic ions, OC, and EC were observed diurnally and between dust and fine particle pollution events (Fig. 6b, c). For instance, the concentrations of $\mathrm{NO}_{3}^{-}$were relatively high in the daytime, while $\mathrm{K}^{+}$and $\mathrm{Cl}^{-}$were more abundant at night. The diurnal cycles can be explained by the formation of secondary particles through photochemical processes during the daytime and by the impacts from biomass and coal burning for heating at night (Dai et al., 2012; Zhang et al., 2018; Cong et al., 2015). The concentrations of $\mathrm{Ca}^{2+}, \mathrm{Mg}^{2+}$, and $\mathrm{Na}^{+}$, which are typically associated with dust in inland areas (Wu et al., 2011), increased sharply during the dust period and then declined rapidly afterwards. 
As discussed, the apparent contribution of VOCs to the formation of SOAs increased when the dusty conditions transitioned into a fine particle pollution event. Temporal changes in the chemical composition of $\mathrm{PM}_{2.5}$ are consistent with this suggestion. During the fine particle pollution period, the concentrations of secondary ions, particularly $\mathrm{NO}_{3}^{-}$, increased as the haze event developed. A similar trend was seen for OC (Fig. 6b), and the content of particulate OC increased from $11.1 \mu^{-3} \mathrm{~m}^{-3}$ in the dust event period to $47.1 \mu \mathrm{g} \mathrm{m}^{-3}$ in the haze period. In another aspect, the ratio of OC/EC increased from 1.3 to 4.9 in the dust-to-haze episode. The previous studies on the characterization of particles from traffic emissions reported OC/EC ratios in the range of 0.28 to 0.92 in diesel vehicles, and the OC/EC ratios were reported as $>2$ in gasoline vehicles (Cadle et al., 1999; Huang et al., 2006). In addition, the OC/EC ratios were reported in the range of 0.9 to 1.6 in the urban region of the city of Guangzhou (Tao et al., 2019). In the present study, the consistent increase in OC/EC would prove the formation of SOAs in the dust-to-haze episode. Combined with the findings regarding the composition of VOCs and $\mathrm{PM}_{2.5}$, these results indicate that the reactions of VOCs led to the formation of SOAs, and in so doing they contributed to the fine particle pollution.

\section{Summary and conclusion}

Comprehensive field work was carried out to investigate the origin and transformation of VOCs within the dust and fine particle pollution periods in winter in the city of Xi' an. The assumption of the promotion of dust on the heterogeneous reactions of VOCs was further verified. Local vehicle exhaust and heating activities were found to be the most important sources of ambient VOCs in Xi' an during winter, while long-range transport air masses have limited impacts. Within the period of dust transport, loading of ambient VOCs decreased sharply from the latter half of the period, and the lowest concentration was observed in the transitional period, in accordance with the aging of primary VOCs. In addition, the loading and proportion of secondary VOCs in the gaseous phase and the secondary ions and organic carbon in the particulate phase increased with the aging of primary VOCs. Source strength, physical dispersion, and regional transport were eliminated as major factors for the variation of the ambient VOCs. Another aspect is the sharp increase in active metal concentrations ( $\mathrm{Ti}$ and $\mathrm{Fe}$ ) and the fast decrease in trans-/cis-2-butene ratios which were observed from the latter half of the dust transport period. In consequence, we conclude that windblown dust might accelerate the solid-gas heterogeneous reactions of atmospheric VOCs and further induce the formation of SOA precursors.
Data availability. All of the research data have been included in the Supplement.

Supplement. The following information is provided in the Supplement: sampling procedures, chemical analysis, source characterization, Figs. S1-S5, and Tables S1-S2. The supplement related to this article is available online at: https://doi.org/10.5194/acp-20-54252020-supplement.

Author contributions. YX designed the study. YX and YH wrote the paper. SSHH, JC, and SL revised the paper. LC and LW analyzed the data. All authors reviewed and commented on the paper.

Competing interests. The authors declare that they have no conflict of interest.

Acknowledgements. Yu Huang was also supported by the "Hundred Talent Program" of the Chinese Academy of Sciences. The authors gratefully acknowledge the NOAA Air Resources Laboratory (ARL) for the provision of the HYSPLIT transport and dispersion model and the READY website (https://www.ready.noaa.gov, last access: 30 April 2020) used in this publication. The data used are listed in the Supplement.

Financial support. This research has been supported by the National Key Research and Development Program of China (grant nos. 2017YFC0212200 and 2016YFA0203000), the National Natural Science Foundation of China (grant nos. 41701565, 21661132005, and 41573138), and the Strategic Priority Research Program of the Chinese Academy of Sciences, China (grant no. XDA23010).

Review statement. This paper was edited by Kimitaka Kawamura and reviewed by three anonymous referees.

\section{References}

Atkinson, R. and Arey, J.: Atmospheric Degradation of Volatile Organic Compounds, Chem. Rev., 103, 4605-4638, https://doi.org/10.1021/cr0206420, 2003.

Cadle, S. H., Mulawa, P. A., Hunsanger, E. C., Nelson, K., Ragazzi, R. A., and Barrett, R.: Composition of lightduty motor vehicle exhaust particulate matter in the Denver, Colorado area, Environ. Sci. Technol., 33, 2328-2339, https://doi.org/10.1021/es9810843, 1999.

Cao, J. J., Wu, F., Chow, J. C., Lee, S. C., Li, Y., Chen, S. W., An, Z. S., Fung, K. K., Watson, J. G., Zhu, C. S., and Liu, S. X.: Characterization and source apportionment of atmospheric organic and elemental carbon during fall and winter of 2003 in Xi' an, China, Atmos. Chem. Phys., 5, 3127-3137, https://doi.org/10.5194/acp5-3127-2005, 2005. 
Chen, H., Nanayakkara, C. E., and Grassian, V. H.: Titanium Dioxide Photocatalysis in Atmospheric Chemistry, Chem. Rev., 112, 5919-5948, https://doi.org/10.1021/cr3002092, 2012.

Chow, J. C., Watson, J. G., Pritchett, L. C., Pierson, W. R., Frazier, C. A., and Purcell, R. G.: The dri thermal/optical reflectance carbon analysis system: description, evaluation and applications in U.S. Air quality studies, Atmos. Environ. A Gen., 27, 11851201, https://doi.org/10.1016/0960-1686(93)90245-T, 1993.

Chow, J. C., Watson, J. G., Chen, L. W. A., Chang, M. C. O., Robinson, N. F., Trimble, D., and Kohl, S.: The IMPROVE_A Temperature Protocol for Thermal/Optical Carbon Analysis: Maintaining Consistency with a Long-Term Database, J. Air Waste Manage., 57, 1014-1023, https://doi.org/10.3155/10473289.57.9.1014, 2007.

Chu, B., Wang, Y., Yang, W., Ma, J., Ma, Q., Zhang, P., Liu, Y., and $\mathrm{He}, \mathrm{H}$.: Effects of $\mathrm{NO}_{2}$ and $\mathrm{C}_{3} \mathrm{H}_{6}$ on the heterogeneous oxidation of $\mathrm{SO}_{2}$ on $\mathrm{TiO}_{2}$ in the presence or absence of UV-Vis irradiation, Atmos. Chem. Phys., 19, 14777-14790, https://doi.org/10.5194/acp-19-14777-2019, 2019.

Cong, Z., Kang, S., Kawamura, K., Liu, B., Wan, X., Wang, Z., Gao, S., and Fu, P.: Carbonaceous aerosols on the south edge of the Tibetan Plateau: concentrations, seasonality and sources, Atmos. Chem. Phys., 15, 1573-1584, https://doi.org/10.5194/acp15-1573-2015, 2015.

Cwiertny, D. M., Young, M. A., and Grassian, V. H.: Chemistry and photochemistry of mineral dust aerosol, Annu. Rev. Phys. Chem., 59, 27-51, https://doi.org/10.1146/annurev.physchem.59.032607.093630, 2008.

Dai, W. T., Ho, S. S. H., Ho, K. F., Liu, W. D., Cao, J. J., and Lee, S. C.: Seasonal and diurnal variations of monoand di-carbonyls in Xi' an, China, Atmos. Res., 113, 102-112, https://doi.org/10.1016/j.atmosres.2012.05.001, 2012.

Dentener, F. J., Carmichael, G. R., Zhang, Y., Lelieveld, J., and Crutzen, P. J.: Role of mineral aerosol as a reactive surface in the global troposphere, J. Geophys. Res., 101, 22869-22889, https://doi.org/10.1029/96JD01818, 1996.

Dickerson, R. R., Kondragunta, S., Stenchikov, G., Civerolo, K. L., Doddridge, B. G., and Holben, B. N.: The Impact of Aerosols on Solar Ultraviolet Radiation and Photochemical Smog, Science, 278, 827-830, https://doi.org/10.1126/science.278.5339.827, 1997.

Duan, J., Guo, S., Tan, J., Wang, S., and Chai, F.: Characteristics of atmospheric carbonyls during haze days in Beijing, China, Atmos. Res., 114, 17-27, https://doi.org/10.1016/j.atmosres.2012.05.010, 2012.

Fan, R., Li, J., Chen, L., Xu, Z., He, D., Zhou, Y., Zhu, Y., Wei, F., and Li, J.: Biomass fuels and coke plants are important sources of human exposure to polycyclic aromatic hydrocarbons, benzene and toluene, Environ. Res., 135, 1-8, https://doi.org/10.1016/j.envres.2014.08.021, 2014.

Fang, Z., Deng, W., Zhang, Y., Ding, X., Tang, M., Liu, T., Hu, Q., Zhu, M., Wang, Z., Yang, W., Huang, Z., Song, W., Bi, X., Chen, J., Sun, Y., George, C., and Wang, X.: Open burning of rice, corn and wheat straws: primary emissions, photochemical aging, and secondary organic aerosol formation, Atmos. Chem. Phys., 17, 14821-14839, https://doi.org/10.5194/acp-17-148212017, 2017.
Feng, T., Bei, N., Huang, R.-J., Cao, J., Zhang, Q., Zhou, W., Tie, X., Liu, S., Zhang, T., Su, X., Lei, W., Molina, L. T., and $\mathrm{Li}, \mathrm{G}$. : Summertime ozone formation in Xi' an and surrounding areas, China, Atmos. Chem. Phys., 16, 4323-4342, https://doi.org/10.5194/acp-16-4323-2016, 2016.

Ginoux, P., Chin, M., Tegen, I., Prospero, J. M., Holben, B., Dubovik, O., and Lin, S. J.: Sources and distributions of dust aerosols simulated with the GOCART model, J. Geophys. Res., 106, 20255-20273, https://doi.org/10.1029/2000jd000053, 2001.

Guo, S., Hu, M., Zamora, M. L., Peng, J. F., Shang, D. J., Zheng, J., Du, Z. F., Wu, Z., Shao, M., Zeng, L. M., Molina, M. J., and Zhang, R. Y.: Elucidating severe urban haze formation in China, P. Natl. Acad. Sci. USA, 111, 17373-17378, https://doi.org/10.1073/pnas.1419604111, 2014.

Guo, S., Hu, M., Lin, Y., Gomez-Hernandez, M., Zamora, M. L., Peng, J., Collins, D. R., and Zhang, R.: OH-Initiated Oxidation of m-Xylene on Black Carbon Aging, Environ. Sci. Technol., 50, 8605-8612, https://doi.org/10.1021/acs.est.6b01272, 2016.

He, H., Wang, Y. S., Ma, Q. X., Ma, J. Z., Chu, B. W., Ji, D. S., Tang, G. Q., Liu, C., Zhang, H. X., and Hao, J. M.: Mineral dust and $\mathrm{NO}_{x}$ promote the conversion of $\mathrm{SO}_{2}$ to sulfate in heavy pollution days, Scientific Reports, 4, 4172, https://doi.org/10.1038/srep04172, 2014.

Ho, K. F., Lee, S. C., Guo, H., and Tsai, W. Y.: Seasonal and diurnal variations of volatile organic compounds (VOCs) in the atmosphere of Hong Kong, Sci. Total. Environ., 322, 155-166, https://doi.org/10.1016/j.scitotenv.2003.10.004, 2004.

Ho, K. F., Lee, S. C., Ho, W. K., Blake, D. R., Cheng, Y., Li, Y. S., Ho, S. S. H., Fung, K., Louie, P. K. K., and Park, D.: Vehicular emission of volatile organic compounds (VOCs) from a tunnel study in Hong Kong, Atmos. Chem. Phys., 9, 7491-7504, https://doi.org/10.5194/acp-9-7491-2009, 2009.

Ho, S. S. H., Ho, K. F., Liu, W. D., Lee, S. C., Dai, W. T., Cao, J. J., and Ip, H. S. S.: Unsuitability of using the DNPH-coated solid sorbent cartridge for determination of airborne unsaturated carbonyls, Atmos. Environ., 45, 261-265, https://doi.org/10.1016/j.atmosenv.2010.09.042, 2011.

Ho, S. S. H., Chow, J. C., Watson, J. G., Wang, L., Qu, L., Dai, W., Huang, Y., and Cao, J.: Influences of relative humidities and temperatures on the collection of $\mathrm{C}_{2}-\mathrm{C}_{5}$ aliphatic hydrocarbons with multi-bed (Tenax TA, Carbograph 1TD, Carboxen 1003) sorbent tube method, Atmos. Environ., 151, 45-51, https://doi.org/10.1016/j.atmosenv.2016.12.007, 2017.

Ho, S. S. H., Wang, L., Chow, J. C., Watson, J. G., Xue, Y., Huang, Y., Qu, L., Li, B., Dai, W., Li, L., and Cao, J.: Optimization and evaluation of multi-bed adsorbent tube method in collection of volatile organic compounds, Atmos. Res., 202, 187-195, https://doi.org/10.1016/j.atmosres.2017.11.026, 2018.

Huang, R., Zhang, Y., Bozzetti, C., Ho, K., Cao, J., Han, Y., Daellenbach, K. R., Slowik, J. G., Platt, S. M., Canonaco, F., Zotter, P., Wolf, R., Pieber, S. M., Bruns, E. A., Crippa, M., Ciarelli, G., Piazzalunga, A., Schwikowski, M., Abbaszade, G., SchnelleKreis, J., Zimmermann, R., An, Z., Szidat, S., Baltensperger, U., Haddad, I. E., and Prevot, A. S. H.: High secondary aerosol contribution to particulate pollution during haze events in China, Nature, 514, 218-222, https://doi.org/10.1038/nature13774, 2014.

Huang, X., Yu, J., He, L., and Hu, M.: Size distribution characteristics of elemental carbon emitted from Chinese vehicles: Results 
of a tunnel study and atmospheric implications, Environ. Sci. Technol., 40, 5355-5360, https://doi.org/10.1021/es0607281, 2006.

Huang, Y., Ling, Z. H., Lee, S. C., Ho, S. S. H., Cao, J. J., Blake, D. R., Cheng, Y., Lai, S. C., Ho, K. F., Gao, Y., Cui, L., and Louie, P. K. K.: Characterization of volatile organic compounds at a roadside environment in Hong Kong: An investigation of influences after air pollution control strategies, Atmos. Environ., 122, 809818, https://doi.org/10.1016/j.atmosenv.2015.09.036, 2015.

Li, B., Ho, S. S. H., Xue, Y., Huang, Y., Wang, L., Cheng, Y., Dai, W., Zhong, H., Cao, J., and Lee, S.: Characterizations of volatile organic compounds (VOCs) from vehicular emissions at roadside environment: The first comprehensive study in Northwestern China, Atmos. Environ., 161, 1-12, https://doi.org/10.1016/j.atmosenv.2017.04.029, 2017.

Liu, W., Zhang, J., Kwon, J., Weisel, C., Turpin, B., Zhang, L., Korn, L., Morandi, M., Stock, T., and Colome, S.: Concentrations and Source Characteristics of Airborne Carbonyl Compounds Measured Outside Urban Residences, J. Air Waste Manage., 56, 1196-1204, https://doi.org/10.1080/10473289.2006.10464539, 2006.

Liu, Y., Shao, M., Fu, L., Lu, S., Zeng, L., and Tang, D.: Source profiles of volatile organic compounds (VOCs) measured in China: Part I, Atmos. Environ., 42, 6247-6260, https://doi.org/10.1016/j.atmosenv.2008.01.070, 2008a.

Liu, Y., Shao, M., Lu, S., Chang, C.-C., Wang, J.-L., and Fu, L.: Source apportionment of ambient volatile organic compounds in the Pearl River Delta, China: Part II, Atmos. Environ., 42, 62616274, https://doi.org/10.1016/j.atmosenv.2008.02.027, $2008 \mathrm{~b}$.

Ndour, M., Conchon, P., D'Anna, B., Ka, O., and George, C.: Photochemistry of mineral dust surface as a potential atmospheric renoxification process, Geophys. Res. Lett., 36, L05816, https://doi.org/10.1029/2008gl036662, 2009.

Ni, H., Huang, R.-J., Cao, J., Liu, W., Zhang, T., Wang, M., Meijer, H. A. J., and Dusek, U.: Source apportionment of carbonaceous aerosols in Xi'an, China: insights from a full year of measurements of radiocarbon and the stable isotope ${ }^{13} \mathrm{C}$, Atmos. Chem. Phys., 18, 16363-16383, https://doi.org/10.5194/acp-18-163632018, 2018.

Nie, W., Ding, A. J., Wang, T., Kerminen, V. M., George, C., Xue, L. K., Wang, W. X., Zhang, Q. Z., Petaja, T., Qi, X. M., Gao, X. M., Wang, X. F., Yang, X. Q., Fu, C. B., and Kulmala, M.: Polluted dust promotes new particle formation and growth, Scientific Reports, 4, 6634, https://doi.org/10.1038/srep06634, 2014.

Perring, A. E., Pusede, S. E., and Cohen, R. C.: An Observational Perspective on the Atmospheric Impacts of Alkyl and Multifunctional Nitrates on Ozone and Secondary Organic Aerosol, Chem. Rev., 113, 5848-5870, https://doi.org/10.1021/cr300520x, 2013.

Rolph, G., Stein, A., and Stunder, B.: Real-time Environmental Applications and Display sYstem: READY, Environ. Modell. Softw., 95, 210-228, https://doi.org/10.1016/j.envsoft.2017.06.025, 2017.

Shao, M., Lu, S. H., Liu, Y., Xie, X., Chang, C. C., Huang, S., and Chen, Z. M.: Volatile organic compounds measured in summer in Beijing and their role in groundlevel ozone formation, J. Geophys. Res., 114, D00G06, https://doi.org/10.1029/2008jd010863, 2009.

Song, S., Gao, M., Xu, W., Sun, Y., Worsnop, D. R., Jayne, J. T., Zhang, Y., Zhu, L., Li, M., Zhou, Z., Cheng, C., Lv, Y., Wang,
Y., Peng, W., Xu, X., Lin, N., Wang, Y., Wang, S., Munger, J. W., Jacob, D. J., and McElroy, M. B.: Possible heterogeneous chemistry of hydroxymethanesulfonate (HMS) in northern China winter haze, Atmos. Chem. Phys., 19, 1357-1371, https://doi.org/10.5194/acp-19-1357-2019, 2019.

Stein, A. F., Draxler, R. R., Rolph, G. D., Stunder, B. J. B., Cohen, M. D., and Ngan, F.: NOAA's HYSPLIT atmospheric transport and dispersion modeling system, B. Am. Meteorol. Soc., 96, 2059-2077, https://doi.org/10.1175/BAMS-D-14$00110.1,2015$.

Tao, J., Zhang, Z., Wu, Y., Zhang, L., Wu, Z., Cheng, P., Li, M., Chen, L., Zhang, R., and Cao, J.: Impact of particle number and mass size distributions of major chemical components on particle mass scattering efficiency in urban Guangzhou in southern China, Atmos. Chem. Phys., 19, 84718490, https://doi.org/10.5194/acp-19-8471-2019, 2019.

Warneke, C., de Gouw, J. A., Edwards, P. M., Holloway, J. S., Gilman, J. B., Kuster, W. C., Graus, M., Atlas, E., Blake, D., Gentner, D. R., Goldstein, A. H., Harley, R. A., Alvarez, S., Rappenglueck, B., Trainer, M., and Parrish, D. D.: Photochemical aging of volatile organic compounds in the Los Angeles basin: Weekday-weekend effect, J. Geophys. Res.-Atmos., 118, 50185028, https://doi.org/10.1002/jgrd.50423, 2013.

Wu, F., Chow, J. C., An, Z., Watson, J. G., and Cao, J.: SizeDifferentiated Chemical Characteristics of Asian Paleo Dust: Records from Aeolian Deposition on Chinese Loess Plateau, J. Air Waste Manage., 61, 180-189, https://doi.org/10.3155/10473289.61.2.180, 2011.

Xu, H., Cao, J., Chow, J. C., Huang, R. J., Shen, Z., Chen, L. W. A., Ho, K. F., and Watson, J. G.: Inter-annual variability of wintertime PM2.5 chemical composition in Xi' an, China: Evidences of changing source emissions, Sci. Total. Environ., 545, 546-555, https://doi.org/10.1016/j.scitotenv.2015.12.070, 2016.

Xue, L., Wang, T., Louie, P. K. K., Luk, C. W. Y., Blake, D. R., and $\mathrm{Xu}, \mathrm{Z}$.: Increasing External Effects Negate Local Efforts to Control Ozone Air Pollution: A Case Study of Hong Kong and Implications for Other Chinese Cities, Environ. Sci. Technol., 48, 10769-10775, https://doi.org/10.1021/es503278g, 2014.

Xue, L. K., Wang, T., Guo, H., Blake, D. R., Tang, J., Zhang, X. C., Saunders, S. M., and Wang, W. X.: Sources and photochemistry of volatile organic compounds in the remote atmosphere of western China: results from the Mt. Waliguan Observatory, Atmos. Chem. Phys., 13, 8551-8567, https://doi.org/10.5194/acp13-8551-2013, 2013.

Xue, Y., Ho, S. S. H., Huang, Y., Li, B., Wang, L., Dai, W., Cao, J., and Lee, S.: Source apportionment of VOCs and their impacts on surface ozone in an industry city of Baoji, Northwestern China, Scientific Reports, 7, 9979, https://doi.org/10.1038/s41598-01710631-4, 2017.

Zhang, D. Z., Shi, G. Y., Iwasaka, Y., and Hu, M.: Mixture of sulfate and nitrate in coastal atmospheric aerosols: individual particle studies in Qingdao $\left(36^{\circ} 04^{\prime} \mathrm{N}, 120^{\circ} 21^{\prime} \mathrm{E}\right)$, China, Atmos. Environ., 34, 2669-2679, https://doi.org/10.1016/s13522310(00)00078-9, 2000.

Zhang, D. Z., Zang, J. Y., Shi, G. Y., Iwasaka, Y., Matsuki, A., and Trochkine, D.: Mixture state of individual Asian dust particles at a coastal site of Qingdao, China, Atmos. Environ., 37, 38953901, https://doi.org/10.1016/s1352-2310(03)00506-5, 2003. 
Zhang, N., Cao, J., Wang, Q., Huang, R., Zhu, C., Xiao, S., and Wang, L.: Biomass burning influences determination based on $\mathrm{PM}_{2.5}$ chemical composition combined with fire counts at southeastern Tibetan Plateau during pre-monsoon period, Atmos. Res., 206, 108-116, https://doi.org/10.1016/j.atmosres.2018.02.018, 2018.

Zhang, Q., Shen, Z., Cao, J., Zhang, R., Zhang, L., Huang, R. J., Zheng, C., Wang, L., Liu, S., Xu, H., Zheng, C., and Liu, P.: Variations in $\mathrm{PM}_{2.5}$, TSP, BC, and trace gases $\left(\mathrm{NO}_{2}, \mathrm{SO}_{2}\right.$, and $\left.\mathrm{O}_{3}\right)$ between haze and non-haze episodes in winter over Xi'an, China, Atmos. Environ., 112, 64-71, https://doi.org/10.1016/j.atmosenv.2015.04.033, 2015.

Zhang, T., Cao, J. J., Tie, X. X., Shen, Z. X., Liu, S. X., Ding, H., Han, Y. M., Wang, G. H., Ho, K. F., Qiang, J., and Li, W. T.: Water-soluble ions in atmospheric aerosols measured in $\mathrm{Xi}$ ' an, China: Seasonal variations and sources, Atmos. Res., 102, 110119, https://doi.org/10.1016/j.atmosres.2011.06.014, 2011.

Zhang, Y., Wang, X., Zhang, Z., Lu, S., Huang, Z., and $\mathrm{Li}$, L.: Sources of $\mathrm{C}_{2}-\mathrm{C}_{4}$ alkenes, the most important ozone nonmethane hydrocarbon precursors in the Pearl River Delta region, Sci. Total Environ., 502, 236-245, https://doi.org/10.1016/j.scitotenv.2014.09.024, 2015.
Zhang, Y., Bao, F., Li, M., Chen, C., and Zhao, J.: NitrateEnhanced Oxidation of $\mathrm{SO} 2$ on Mineral Dust: A Vital Role of a Proton, Environ. Sci. Technol., 53, 10139-10145, https://doi.org/10.1021/acs.est.9b01921, 2019.

Zhang, Z., Wang, X., Zhang, Y., Lü, S., Huang, Z., Huang, X., and Wang, Y.: Ambient air benzene at background sites in China's most developed coastal regions: Exposure levels, source implications and health risks, Sci. Total Environ., 511, 792-800, https://doi.org/10.1016/j.scitotenv.2015.01.003, 2015.

Zou, Y., Deng, X. J., Zhu, D., Gong, D. C., Wang, H., Li, F., Tan, H. B., Deng, T., Mai, B. R., Liu, X. T., and Wang, B. G.: Characteristics of 1 year of observational data of VOCs, $\mathrm{NO}_{x}$ and $\mathrm{O}_{3}$ at a suburban site in Guangzhou, China, Atmos. Chem. Phys., 15, 6625-6636, https://doi.org/10.5194/acp-15-6625-2015, 2015. 